\title{
GENETIC EVALUATION OF GROWTH AND SURVIVAL AT 6 WEEKS OLD FRY OF EGYPTIAN NILE TILAPIA (OREOCHROMIS NILOTICUS) BETWEEN IMPROVED ABBASSA AND COMMERCIAL MANZALA STRAINS IN A DIALLEL CROSSING
}

\author{
M.M. Said ${ }^{1}$ and W. Mekkawy ${ }^{2,3}$
}

1- Aquaculture Department, Faculty of Fish Resources, Suez University, Suez, Egypt, 2- Animal Production Department, Faculty of Agriculture, Ain Shams University, Cairo, Egypt, 3- World Fish, Penang, Malaysia

\section{SUMMARY}

This study aims to evaluate growth performance and estimate additive genetic, heterosis, and general reciprocal effects for body weight, body length, condition factor, and survival of Nile tilapia (Oreochromis niloticus) fry at 6 weeks old after hatching using a complete diallel cross between the genetically improved "Abbassa" strain(A) and a commercially available strain Manzala(M). Body weight and total body length were observed significantly $(P<0.001)$ higher in $M_{m} A_{f}$ and $A_{m} M_{f}$ crosses $(2.87 \mathrm{~g} \& 5.55 \mathrm{~cm} ; 2.78 \mathrm{~g} \& 5.33 \mathrm{~cm}$, respectively). The straight-bred $A_{m} A_{f}$ weight and length were $2.64 \mathrm{~g}, 5.18 \mathrm{~cm}$, respectively while the straightbred $M_{m} M_{f}$ showed the lowest growth parameters $2.42 \mathrm{~g}$ and $5.04 \mathrm{~cm}$,respectively. Condition factor of $A_{m} A_{f}$, $A_{m} M_{f}$, and $M_{m} M_{f}$ genotypes $\left(1.89,1.85\right.$, and 1.81 respectively) didn't differ significantly whereas the $M_{m} A_{f}$ cross showed a significantly lower condition factor 1.67. The survival of the straight-bred $A_{m} A_{f}$ was 0.98 , which significantly $(P<0.001)$ higher than $A_{m} M_{f}, M_{m} A_{f}$, and $M_{m} M_{f}$ genotypes. Abbassa strain showed 5, 2.1, and 10\% additive genetic effect above the overall mean in body weight, survival, and condition factor respectively. Heterosis estimates were positive and relatively high $11.7 \%$ and $6.2 \%$ for body weight and total body length while a negative heterosis estimates were observed for the condition factor and survival, being $-6.7 \%$ and $-2.6 \%$ respectively. Reciprocal effect was significant $(P<0.001)$ for total body length and condition factor. The results of the current study suggest that body weight and total body length of the Nile tilapia fry at 6 weeks old after hatching could be improved through crossing schemes exploiting the heterosis effect however the crossing did not show any improvement in survival.

Keywords: additive variance, heterosis, reciprocal effect, Nile tilapia fry

\section{INTRODUCTION}

In Egypt, tilapia contributes about $60 \%$ of the total aquaculture production. Between 2003 and 2013 tilapia production showed a dramatic increase from 200,000 to 635,843 tons, representing an annual increase of $12 \%$. Moreover, Egyptian Nile tilapia (Oreochromis niloticus) is being produced from many culture systems including ponds, cages, tanks, and large water bodies (GAFRD, 2004 and 2014). Such improvement on the Egyptian tilapia production aspects could be accompanied with a similar improvement in all production constrains such as production of balanced formulated feeds, adoption of advanced management techniques, development of improved strains, and potentially viable hybrids.

A genetic stock improvement programme for Nile tilapia has been conducted by World Fish in Egypt since 2002 in order to develop an improved tilapia strain, which has been named as the "Abbassa strain" (Rezk et al., 2009). Ibrahim et al.(2013) concluded that the Abbassa strain is ready to release for tilapia industry in Egypt based on superior on-station performance compared to a widely and locally available commercial tilapia strain.

Egyptian tilapia hatcheries sell tilapia seeds to fish famers at 3-4 weeks after hatching with an average weight $0.2-0.5 \mathrm{~g}$ or they keep the fry for another 4-6 weeks before they sell them as fingerlings, weighing 1 - $5 \mathrm{~g}$ (Saleh, 2007 and Nasr-
Allah et al., 2012). In addition, many studies reported that the stocking and harvest weights of Nile tilapia are positively and highly correlated (Abdel-Hakim et al., 2008 and Ammar, 2009).

The main objectives of this study were to evaluate growth performance and estimate line crossing parameters of improved Abbassa tilapia strain and a commercial Manzala strain within a complete diallel cross at 6 weeks old after hatching. This is done in order to determine the optimum utilization of these strains and crosses for the production of premium growth and survival of tilapia seeds.

\section{MATERIALS AND METHODS}

\section{Origin of stocks:}

This study included two sources of Nile tilapia: Abbassa improved strain, which has described in detail by Rezk et al. (2009) and Khaw et al. (2009) and commercial Manzala strain The Abbassa strain was obtained from World Fish Regional Center, Abbassa, Abu-Hamad, Sharkia, Egypt, and the Manzala strain was obtained from a commercial Nile tilapia hatchery, located at Manzala, Dakahlia, Egypt. Descriptive statistics of body measurement for the brood fish from both the sources, Abbassa and Manzala, are represented in Table (1). The study was carried out at a commercial fish hatchery at San ElHagar El-Bharia, Sharkia, Egypt from $1^{\text {st }}$ of June 2015 and lasted for 10 weeks. 
Table 1. Descriptive statistics for body measurements of brood stock of two different Nile tilapia strains

\begin{tabular}{lcccccccc}
\hline & \multicolumn{4}{c}{ Males } & \multicolumn{4}{c}{ Females } \\
\cline { 2 - 11 } Strain & Length & Weight & Depth & Girth & Length & Weight & Depth & Girth \\
\hline Abbassa (A) & 20.6 & 158.6 & 7.2 & 15.3 & 20.3 & 149.8 & 6.4 & 13.9 \\
Manzala (M) & 20.5 & 142.7 & 7.25 & 16.2 & 22.3 & 168.8 & 7.3 & 16.1 \\
\hline
\end{tabular}

\section{Mating design:}

A complete diallel crossing was made to obtain all four possible combinations of genotypes. Three replicates were formed from each mating; each replicate consisted of two males and six females. The breeding groups were stocked in separate $1 \times 2 \times 1 \mathrm{~m}$ breeding hapas. A total of 12 breeding hapas were installed in $1000 \mathrm{~m}^{2}$ earthen pond. After 14 days, swim-up fry were collected separately from each hapa and transferred to $1 \times 2 \times 1 \mathrm{~m}$ rearing hapas at a stocking density of 200 fry per $\mathrm{m}^{2}$ for further rearing until 6 weeks after hatching (a.h.).

\section{Fish Management:}

All hatchery ponds were in a static water system with a temperature range $24-29^{\circ} \mathrm{C}$ during the study. Approximately $20 \%$ of the water was replaced daily with clean water to maintain a good water quality. Brood fish were fed two times a day with a pelleted commercial feed containing 35\% crude protein @ 2\% of their average body weights. The resulting progeny were fed on a compound commercial diet containing $45 \%$ crude protein and $8 \%$ fat and were manually fed ad libitum, four times a day during day light hours.

\section{Considered Traits:}

Body weight and length: 30 fry per hapa were randomly chosen and individually weighed $(\mathrm{g})$ and total length measured $(\mathrm{cm})$ at six weeks old after hatching; Condition Factor (K):Condition factor was calculated for the 30 chosen fry per hapa according to the formula: $\mathrm{K}=\left(\right.$ Weight $(\mathrm{g}) /$ Length $\left.(\mathrm{cm})^{3}\right) \times 100$ (Le Cren, 1951); and survival at six weeks old was treated as a binary trait, for each hapa the counted alive fish at the end of the experiment were coded as ' 1 ', whereas the counted dead ones coded as ' 0 '.

\section{Statistical analysis:}

For each trait, two different statistical models were used for the analysis. The first included the fixed effects of genotype (4 levels) and hapa nested within genotype (12 levels). The differences between the means of the genotypes were tested using Bonferroni test (Bonferroni, 1936).

To further partition of the difference between the four mating groups and in order to estimate the additive genetic, heterosis and general reciprocal effects a multiple regression model was used as follow:

$$
\boldsymbol{Y}_{i j k}=\boldsymbol{\mu}+\sum \mathbf{k}_{\mathrm{i}} \mathbf{a}_{\mathrm{i}}+\sum \mathbf{k}_{\mathrm{ij}} \mathbf{h}_{\mathrm{ij}}+\sum \mathbf{t}_{\mathrm{i}} \mathbf{r}_{\mathrm{i}}+\boldsymbol{e}_{i j \mathrm{k}}
$$

Where $Y_{i j k}$ represents the observation on the $k^{\text {th }}$ progeny produced from the $\mathrm{i}^{\text {th }}$ and $\mathrm{j}^{\text {th }}$ strain. $\mathrm{k}_{\mathrm{i}}$ is the proportion of genes contributed by the $\mathrm{k}^{\text {th }}$ individual originating from the $\mathrm{i}^{\text {th }}$ strain $\left(\mathrm{k}_{\mathrm{i}}=0.0,0.5\right.$ or 1.0 and $\left.\Sigma \mathrm{k}_{\mathrm{i}}=1.0\right) ; \mathrm{a}_{\mathrm{i}}$ is the additive genetic effect of genes originating from the $i^{\text {th }}$ strain; $k_{i j}$ is the coefficient of the total heterosis effect for the cross between the $\mathrm{i}^{\text {th }}$ and $\mathrm{j}^{\text {th }}$ strains $\left(\mathrm{k}_{\mathrm{ij}}=0.0\right.$ or $1.0 ; \mathrm{i} \neq \mathrm{j}$ and $\mathrm{ij} \neq \mathrm{ji}$ and $\Sigma \mathrm{k}_{\mathrm{ij}}$ $=1.0) ; h_{i j}$ is the total heterosis effect for the cross between the $i^{\text {th }}$ and $j^{\text {th }}$ strains $(i \neq j$ and $i j \neq j i) ; t_{i}$ is the coefficient of the general reciprocal effect for the $i^{\text {th }}$ strain $\left(\mathrm{t}_{\mathrm{i}}=0\right.$ for purebreds and -0.5 for male strain and 0.5 for female strain, for the crossbreds and $\Sigma \mathrm{t}_{\mathrm{i}}=1.0$ ); $r_{i}$ is the general reciprocal effect of the $i^{\text {th }}$ strain; the set of coefficients for the general reciprocal effects assume that the additive effects of the genes of a given strain are similar regardless whether the genes are inherited through a male or female according to Gjerde et al. (2002) see Table 2; and $\mathrm{e}_{\mathrm{ijk}}$ is the random residual associated with the individual observations on each fish. All analyses were conducted using SPSS (2013).

Table 2. Illustration of the coding for the coefficients of the additive genetic $\left(a_{i}\right)$, total heterosis $\left(h_{i j}\right)$ and general reciprocal $\left(r_{i}\right)$ effects used in multiple regression model

\begin{tabular}{ccccccc} 
Strain /cross & Overall mean & \multicolumn{2}{c}{ Additive genetic } & Total heterosis & \multicolumn{2}{c}{ General reciprocal } \\
\cline { 2 - 7 } & \multicolumn{1}{c}{$\mathrm{a}_{\mathrm{A}}$} & $\mu$ & $\mathrm{a}_{\mathrm{M}}$ & $\mathrm{h}_{\mathrm{AXM} \text { or MXA }}$ & $\mathrm{r}_{\mathrm{A}}$ & $\mathrm{r}_{\mathrm{M}}$ \\
\hline A X A & 1 & 1.0 & 0.0 & 0.0 & 0.0 & 0.0 \\
A X M & 1 & 0.5 & 0.5 & 1.0 & -0.5 & 0.5 \\
M X A & 1 & 0.5 & 0.5 & 1.0 & 0.5 & -0.5 \\
M X M & 1 & 0.0 & 1.0 & 0.0 & 0.0 & 0.0 \\
\hline
\end{tabular}

As in Gjerde et al., 2002

\section{RESULTS AND DISCUSSION}

Basic analysis:

Analysis of variance revealed that the effect of genotype was significant $(\mathrm{P}<0.001)$ for all studied traits of Nile tilapia fry at 6 weeks old a.h.
(Table3).The differences among genotypes were collectively highly significant according to the fixed effect model. The hapa had no significant effect on the growth, which might be due to the relative short time where the fish kept for in the hapas (6 weeks). 
Analysis of variance (Table 4) shows that the body weight and total body length of 6 weeks old Nile tilapia fry were significantly higher in $\mathrm{M}_{\mathrm{m}} \mathrm{A}_{\mathrm{f}}$ and $\mathrm{A}_{\mathrm{m}} \mathrm{M}_{\mathrm{f}}$ crosses $(2.87 \mathrm{~g}, 5.55 \mathrm{~cm}$ and $2.78 \mathrm{~g}, 5.33 \mathrm{~cm}$, respectively). Moreover, the straight-bred $\mathrm{A}_{\mathrm{m}} \mathrm{A}_{\mathrm{f}}$ weight and length were $2.64 \mathrm{~g}, 5.18 \mathrm{~cm}$, respectively while the straight-bred $\mathrm{M}_{\mathrm{m}} \mathrm{M}_{\mathrm{f}} \mathrm{s}$ showed the lowest growth performance $(2.42 \mathrm{~g}, 5.04 \mathrm{~cm}$, respectively). These results indicate that crossing of the Abbassa strain with commercial Manzala strain can improve the body weight and total body length of 6 weeks old Nile tilapia fry. Table 4 revealed that condition factor of $\mathrm{A}_{\mathrm{m}} \mathrm{A}_{\mathrm{f}}, \mathrm{A}_{\mathrm{m}} \mathrm{M}_{\mathrm{f}}$, and $\mathrm{M}_{\mathrm{m}} \mathrm{M}_{\mathrm{f}}$ genotypes (1.89, 1.85, and 1.81 respectively)doesn't differ significantly while $\mathrm{M}_{\mathrm{m}} \mathrm{A}_{\mathrm{f}}$ cross showed a significantly lower condition factor of 1.67. Survival of the straight-bred
$\mathrm{A}_{\mathrm{m}} \mathrm{A}_{\mathrm{f}}$ was a significantly higher (0.98) whereas the survival of $\mathrm{M}_{\mathrm{m}} \mathrm{M}_{\mathrm{f}}, \mathrm{M}_{\mathrm{m}} \mathrm{A}_{\mathrm{f}}$, and $\mathrm{A}_{\mathrm{m}} \mathrm{M}_{\mathrm{f}}$ genotypes (0.94, 0.94 , and 0.92 respectively) didn't differ significantly from each other. The survival for crossbreds was lower than pure strains, which led to slightly lower density in the crossbred hapas to enhance the growth for the crossbred. However, it was not possible to include the survival rate in each hapa as a covariate in the fixed effect model because it is confounded with the hapa effect. We dropped the hapa effect from the fixed effect model and fitted survival within each hapa as a covariate (results are not shown). The survival rate had no significant effect on the body weight, body length or condition factor.

Table 3. Analysis of variance for body weight $(\mathrm{g})$, body length $(\mathrm{cm})$, condition factor, and survival rate of different genotypes of Nile tilapia fry at 6 weeks old after hatching according to the fixed effect model

\begin{tabular}{lcccccccccccc}
\hline & \multicolumn{3}{c}{ Body weight } & \multicolumn{4}{c}{ Body length } & \multicolumn{3}{c}{ Condition factor } & \multicolumn{3}{c}{ Survival } \\
\cline { 2 - 14 } Source of Variance & Df & SS & Sig & Df & SS & Sig & Df & SS & Sig & Df & SS & Sig \\
\hline Genotype & 3 & 10.5 & $* * *$ & 3 & 12.6 & $* * *$ & 3 & 2.3 & $* * *$ & 3 & 1.05 & $* * *$ \\
Hapa(genotype) & 8 & 6.6 & Ns & 8 & 2.08 & Ns & 8 & 0.3 & Ns & 8 & 2.6 & $* * *$ \\
Error & 348 & & & 348 & & & 348 & & & 2388 & \\
Corrected total & 359 & & & 359 & & & 359 & & & 2399 &
\end{tabular}

Asterisks or Ns across classification indicate the significance or absence of it as a source of variation; $* * *=$ significant at $\mathrm{p} \leq 0.001$.

Table 4. Least squares means for body weight $(\mathrm{g})$, body length $(\mathrm{cm})$, condition factor, and survival rate from complete $2 \times 2$ diallel crossing of Nile Tilapia fry at 6 weeks old after hatching according to multiple regression model

\begin{tabular}{lcccc}
\hline Genotype & Body weight \pm SE & Body length & $\begin{array}{c} \pm S E \\
\text { Condition factor } \\
\pm \text { SE }\end{array}$ & $\begin{array}{c}\text { Survival } \\
\pm \text { SE }\end{array}$ \\
\hline $\mathrm{A}_{\mathrm{m}} \mathrm{A}_{\mathrm{f}}$ & $2.64^{\mathrm{ab}} \pm 0.066$ & $5.18^{\mathrm{bc}} \pm 0.048$ & $1.89^{\mathrm{a}} \pm 0.025$ & $0.983^{\mathrm{a}} \pm 0.009$ \\
$\mathrm{M}_{\mathrm{m}} \mathrm{M}_{\mathrm{f}}$ & $2.42^{\mathrm{b}} \pm 0.066$ & $5.04^{\mathrm{c}} \pm 0.048$ & $1.85^{\mathrm{a}} \pm 0.025$ & $0.940^{\mathrm{b}} \pm 0.009$ \\
$\mathrm{~A}_{\mathrm{m}} \mathrm{M}_{\mathrm{f}}$ & $2.78^{\mathrm{a}} \pm 0.066$ & $5.33^{\mathrm{b}} \pm 0.048$ & $1.81^{\mathrm{a}} \pm 0.025$ & $0.927^{\mathrm{b}} \pm 0.009$ \\
$\mathrm{M}_{\mathrm{m}} \mathrm{A}_{\mathrm{f}}$ & $2.87^{\mathrm{a}} \pm 0.066$ & $5.55^{\mathrm{a}} \pm 0.048$ & $1.67^{\mathrm{b}} \pm 0.025$ & $0.947^{\mathrm{b}} \pm 0.009$ \\
\hline
\end{tabular}

ab...Within classification any two means having the same script are not significantly different using Bonferroni test $\mathrm{p} \leq 0.05$.

Regarding the comparative performance of the experimental strains as pure breeding groups, Abbassa strain showed a noted superiority over the commercial strain Manzala concerning all traits including body weight (9\%), total body length $(2.7 \%)$, condition factor $(4.4 \%)$, and survival $(4.5 \%)$ at 6 weeks old a.h. (Table 4). Abbassa strain growth superiority could be due to that it was developed by genetic selection to improve growth for a number of generations. The current results were relatively in agreement with Ibrahim et al., 2013who compared between Abbassa stain and another Egyptian commercial strain ie. Kafr El Sheikh. The study concluded that Abbassa strain showed a higher harvest weight $(28 \%)$ than that of the Kafr El Sheikh strain and that both strains had a similar survival rate (approximately 80\%) during the grow-out period.

\section{Strain additive genetic effect:}

Many studies reported variable significances of the additive genetic effect within a diallel crossing concerning growth performance of tilapia (Bentsen et al., 1998; Hussain et al. 2000a; 2000b; Maluwa and Gjerde 2006; Nguyen et al., 2009;Pongthana et al., 2010; Ngo et al., 2016), salinity and cold tolerance of tilapia (Gnaani et al., 2000; and Armas-Rosales 2006), growth and survival of rohu carp (Gjerdeetal.,2002), and growth of fresh water prawn (Pillai et al., 2011).Results of parameters estimates (Table 6) showed that the Abbassa strain had a positive additive genetic value of $5,2.1$, and $10 \%$ above the overall mean for body weight, survival, and condition factor respectively. However, the Abbassa strain also showed a negative additive genetic value for total body length at 6 weeks old a.h. with about $-1.3 \%$ below the overall mean but this effect was not significant. 


\section{Heterosis:}

Negative or low estimates of heterosis were reported in diallel crossing experiments that investigate growth performance and survival rate of tilapia (Bentsen et al., 1998; Pongthana et al., 2010; Ngo et al., 2016), Rohu carp (Gjerde et al., 2002), and Giant freshwater prawn (Thanh et al., 2010). In contrast highly significant heterosis estimates were obtained within other diallel crossing schemes eg., Common carp (Bakos \& Gorda 1995), Channel catfish (Argue, Liu \& Dunham 2003), and Maluwa \& Gjerde 2006 who reported a total heterosis of $15.3 \%$ for harvest body weight of Oreochromis shiranus. According to the obtained heterotic effects, alternative breeding strategies were recommended for simultaneous improvement of the target traits in each study. Analysis of variance (Table 5) revealed that heterosis was significant $(\mathrm{P}<0.001)$ in all studied traits including body weight, body length, condition factor, and survival of Nile tilapia fry at 6 weeks old after hatching. Parameters estimates (Table 6) shows that heterosis were relatively high $11.7 \%$ and $6.2 \%$ in body weight and total body length of 6 weeks old a.h., respectively. Such a significant effect of heterosis could be explained by genetic differences in allele frequencies between the experimental strains. The Abbassa strain has been kept and used for many generations by World Fish for a selective breeding program in a closed breeding nucleus and they were not mixed with other strains. Consequently, crossing of these two strains could increase the levels of heterozygosity in the crossbred and explain the heterosis effects observed in the current study. Furthermore, our results indicated that Abbassa and Manzala strains have a high nicking ability (also referred to as "combining ability"), which can be utilized in crossbreeding schemes to exploit high non-additive gene effects in the production of Nile tilapia fry. This indication can be optimized through applying reciprocal recurrent selection to maximize this effect. Table 6 shows that heterosis estimates were negative $-6.7 \%$ and $-2.6 \%$ for the condition factor and survival, respectively. The crossbreeding has improved the growth in the current study, however, it had a slightly negative effect on survival. The overall gain from body weight in the crossbred (11.7\%) will compensate and exceed the loss in survival $(-2.6 \%)$.

\section{Reciprocal effects:}

Results (Table 5) indicated that reciprocal effect was significant $(\mathrm{P}<0.001)$ for total body length and condition factor while it was non-significant for both body weight and survival of Nile tilapia fry at 6 weeks old. So, our results indicated that using either of these two strains as male or female parents in the planning of crossbreeding programs for the production of Nile tilapia fry would not affect the weight and survival of fry at 6 weeks old a.h.

Table 5. Analysis of variance for body weight $(\mathrm{g})$, body length $(\mathrm{cm})$, condition factor, and survival rate from complete 2 X 2 diallel crossing of Nile tilapia fry at 6 weeks old after hatching according to multiple regression model

\begin{tabular}{|c|c|c|c|c|c|c|c|c|c|c|c|c|}
\hline \multirow[b]{2}{*}{$\begin{array}{l}\text { Source of } \\
\text { variance }\end{array}$} & \multicolumn{3}{|c|}{ Body weight } & \multicolumn{3}{|c|}{ Body length } & \multicolumn{3}{|c|}{ Condition factor } & \multicolumn{3}{|c|}{ Survival } \\
\hline & Df & SS & Sig. & Df & SS & Sig. & Df & SS & Sig. & Df & SS & Sig. \\
\hline Additive A & 1 & 0.35 & Ns & 1 & 0.12 & Ns & 1 & 0.7 & $* * *$ & 1 & 0.08 & Ns \\
\hline $\mathrm{He}$ & 1 & 8.01 & $* * *$ & 1 & 9.59 & $* * *$ & 1 & 1.36 & $* * *$ & 1 & 0.37 & $* * *$ \\
\hline $\operatorname{Rec}$ & 1 & 0.39 & Ns & 1 & 2.1 & $* * *$ & 1 & 0.88 & $* * *$ & 1 & 0.12 & Ns \\
\hline Error & 356 & 146.2 & & 356 & 76.1 & & 356 & 19.9 & & 2396 & 114.7 & \\
\hline Corrected & 359 & 156.7 & & 359 & 88.8 & & 359 & 22.2 & & 2399 & 115.8 & \\
\hline
\end{tabular}

total

Asterisks or Ns across classification indicate the significance or absence of it as a source of variation; $* * *=$ significant at $\mathrm{p} \leq 0.001$.

Table 6. Parameters estimates for body weight $(\mathrm{g})$, body length $(\mathrm{cm})$, condition factor, and survival rate from complete 2 X2 diallel crossing of Nile Tilapia fry at 6 weeks old after hatching according to multiple regression model

\begin{tabular}{lcccc}
\hline & Body weight \pm SE & Body length \pm SE & Condition factor \pm SE & Survival \pm SE \\
\hline Intercept & $2.46 \pm 0.83$ & $5.15 \pm 0.06$ & $1.78 \pm 0.03$ & $0.95 \pm 0.01$ \\
Additive A & $0.12 \pm 0.13$ & $-0.07 \pm 0.09$ & $0.17 \pm 0.05$ & $0.023 \pm 0.01$ \\
He & $0.29 \pm 0.06$ & $0.32 \pm 0.04$ & $-0.12 \pm 0.02$ & $-0.025 \pm 0.009$ \\
Rec & $0.09 \pm 0.09$ & $0.21 \pm 0.06$ & $-0.14 \pm 0.03$ & $0.02 \pm 0.01$ \\
\hline
\end{tabular}

\section{CONCLUSION}

The current study showed that, body weight and total body length of the Nile tilapia fry at 6 weeks old a.h. could be improved using the non-additive genetic effects between the selection strain Abbassa and commercial strain Manzala. The crossing had a slightly negative effect on the survival however the enhanced growth of the crossbred was higher than the reduction in production because of the lower survival for the crossbred fry. 


\section{ACKNOWLEDGEMENTS}

We thank Dr. Curtis Lind for his constructive comments and suggestions.

\section{REFERENCES}

Abdel-Hakim N.F., A. A. Ammar, and A. S. AbdElgawad, 2008. Effect of initial stocking size and production cycle on growth performance of mono sex tilapia reared in earthen ponds. 8th International Symposium on Tilapia in Aquaculture, 255:269.

Argue B.J., Z. Liu, and R.A. Dunham, 2003. Dressout and fillet yields of channel catfish, Ictalurus punctatus, bluecatfish, Ictalurusfurcatus, and their F 1, F 2 and backcross hybrids. Aquaculture 228, 81-90.

Armas-Rosales A.M., 2006. Genetic Effects Influencing Salinity and Cold Tolerance in Tilapia. University of Stirling, Scotland.

Ammar A. A., 2009. Effect of initial weight and stocking density on growth performance of mono sex Nile tilapia reared in semi intensive system. Egypt J. Aquat. Biol. \& Fish., Vol. 13, No. 2: 6980.

Bakos J. and S. Gorda, 1995. Genetic improvement of common carp strains using intraspecific hybridization. Aquaculture 129, 183-186.

Bentsen H.B., A. E. Eknath, M.S. Palada-de Vera, J.C. Danting, H.L. Bolivar, R.A. Reyes, E.E. Dionisio, F.M. Longalong, A.V. Circa, M.M. Tayamen, and B. Gjerde, 1998. Genetic improvement of farmed tilapias: growth performance in a complete diallel cross experiment with eight strains of Oreochromis niloticus. Aquaculture 160, 145-173.

Bonferroni, C. E., 1936. Teoria statistica delle classi e calcolo delle probabilità." Pubblicazioni del R Istituto Superiore di Scienze Economiche e Commerciali di Firenze 8, 3-62.

GAFRD, 2004. General Authority for Fish Resources Development. Annual fishery statistics report, Ministry of Agriculture and Land Reclamation, Cairo, Egypt.

GAFRD, 2013. General Authority for Fish Resources Development. Annual fishery statistics report, Ministry of Agriculture and Land Reclamation, Cairo, Egypt.

Gjerde B., P.V.G.K. Reddy, K.D. Mahapatra, J.N. Saha, R.K. Jana, P.K. Meher, M. Sahoo, S.L enka, P. Govindassamy, and M. Rye 2002. Growth and survival in two complete diallele crosses with five stocks of Rohu carp (Labeorohita). Aquaculture 209, 103-115.

Gnaani A., G. Gall, and G. Hulata, 2000. Cold tolerance of tilapia species and hybrids. Aquaculture International 8, 289-298.

Hussain, M.G., A.H.M. Kohinoor, M.S. Islam, S.C. Mahata, M.Z. Ali, M. Tanu, M.A., Hossain, and M.A. Mazid 2000a. Genetic evaluation of GIFT and existing strains of Nile tilapia, Oreochromis niloticus, under on-station and on-farm conditions of Bangladesh. Asian Fish. Science, 13(2):117126 .

Hussain, M.G., A.H.M. Kohinoor, A. Hossain, M.A. Mazid, and M.M. Dey, 2000b. Growth and production performances of GIFT strain of Nile tilapia, Oreochromis niloticus L., under different farming conditions in Bangladesh. J. Aqua. Trop. 15(3): 273-280.

Ibrahim N. A., M.Y. Abou Zaid, L. K. Hooi, G. O. El-Naggar, R. W. Ponzoni, 2013. Relative performance of two Nile tilapia (Oreochromis niloticus Linnaeus) strains in Egypt: The Abbassa selection line and the Kafr El Sheikh commercial strain. Aquaculture Research, 2013, 44, 508-517

Khaw H.L., H. Bovenhuis, R.W. Ponzoni, M.A. Rezk, H. Charo-Karisa, and H. Komen, 2009. Genetic analysis of Nile tilapia (Oreochromis niloticus) selection line reared in two input environments. Aquaculture 294, 37-42.

LE CREN, E.D. 1951. The length-weight relationship and seasonal cycle in gonad weight and conditions in the perch Percafluviatilis. J. Animal Ecol.,, London, 20 (2): 201-219.

Maluwa A.O. and B. Gjerde 2006. Genetic evaluation of four strains of Oreochromis shiranus for harvest body weight in a diallel cross. Aquaculture 259, 28-37.

Nasr-Allah A. M., M. W. Dexon, D. A. Al-Kenawy, M. Fathy, G. O. El_Nagar, 2014. Technical characteristics and economic performance of commercial tilapia hatcheries applying different management systems in Egypt. Aquaculture, 426427, 222-230.

Ngo P. T., H. N. Nguyen, T. H. Nguyen, K. Wayne, H. D. Nguyen, and H. N. Nguyen, 2016. Additive genetic and heterotic effects in a 4 X 4 complete diallel cross-population of Nile tilapia (Oreochromis niloticus, Linnaeus, 1758) reared in different water temperature environments in Northern Vietnam. Aquaculture Research, 47, 708-720.

Pillai B.R., K.D. Mahapatra, R.W. Ponzoni, L. Sahoo, P.L. Lalrinsanga, N.H. Nguyen, S. Mohanty, S. Sahu, S. Vijaykumar, H.L. Sahu, Khaw, G. Patra, S. Patnaik, and S.C. Rath, 2011. Genetic evaluation of a complete diallel cross involving three populations of freshwater prawn (Macrobrachium rosenbergii) from different geographical regions of India. Aquaculture 319, 347-354.

Pongthana N., N.H. Nguyen, and R.W. Ponzoni 2010. Comparative performance of four red tilapia strains and their crosses in fresh-and saline water environments. Aquaculture 308, 109-114.

Thanh N.M., N.H. Nguyen, R.W. Ponzoni, N.T. Vu, A.C. Barnes, and P.B. Mather, 2010. Estimates of strain additive and non-additive genetic effects for growth traits in a diallel cross of three strains of giant freshwater prawn (Macrobrachium rosenbergii) in Vietnam. Aquaculture 299, 30-36. 
Rezk M.A., R.W. Ponzoni, E. Kamel, G. John, T.

Dawood, H.L. Khaw, and M. Megahed, 2009.

Selective breeding for increased body weight in a synthetic breed of Egyptian Nile tilapia, Oreochromis niloticus: Response to selection and genetic parameters. Aquaculture 293, 187-194.

Saleh, M.A., 2007. Freshwater fish seed resources in

Egypt. In: Bondad-Reantaso, M.G. (Ed.),
Assessment of Freshwater Fish Seed Resources for Sustainable Aquaculture, FAO Fisheries Technical Paper. FAO, Rome, pp. 241-255.

SPSS 2013. IBM Corp. Released 2013. IBM SPSS Statistics for Windows, Version 22.0. Armonk, NY: IBM Corp.

\section{التقييم الوراثى للنمو والبقاء على عمر ج اسابيع لزريعه البلطى النيلى من خلال الخلط بين سلالتى العباسه المحسنة والمنزلة التجارية التورية \\ محمد محمد سعيد' ، وجدى أحمد مكاوى r،}

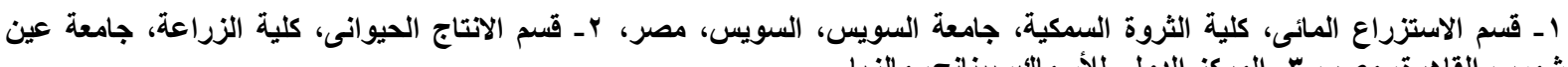
شمس، القاهرة، مصر، بـــ المركز الدولى للأسماك، بينانج، مالزيا

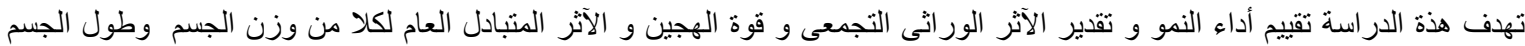

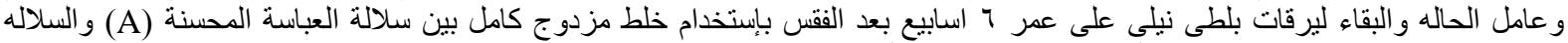

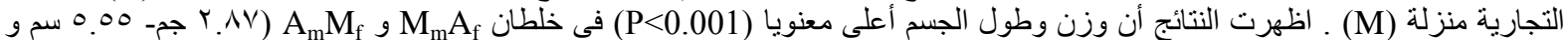

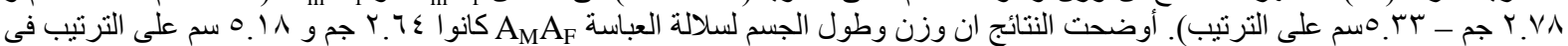

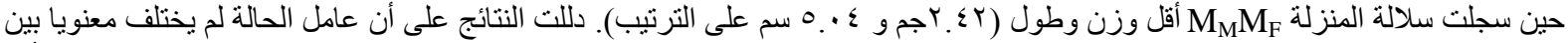

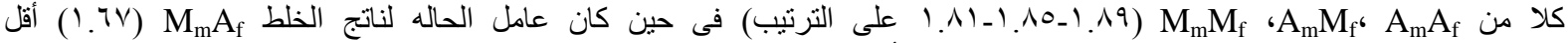

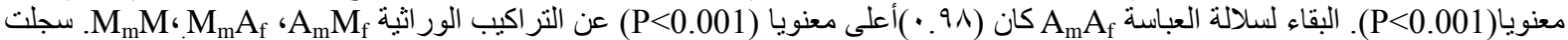

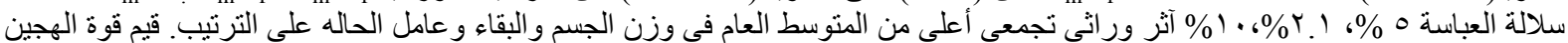

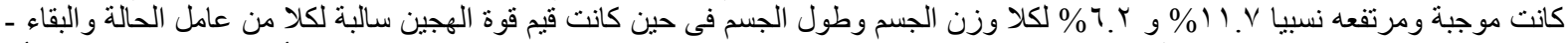

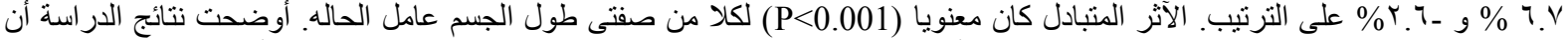

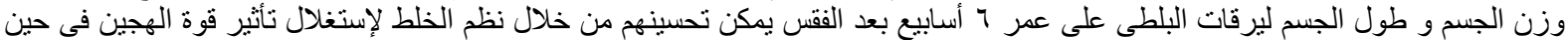
أن الخط لم يظهر اية تحسين فى الجقاء. 